\title{
Editorial: The Urban Sociology of Detroit
}

\author{
Hilary Silver \\ Brown University
}

This is my last issue as Editor of City $\mathcal{E}$ Community, an appropriate place to thank those who wrote and reviewed for the journal during my two terms. It was a privilege to serve with the longstanding senior Associate Editors, Nancy Denton and Sharon Zukin, who provided wise counsel, intellectual guidance, and good sense. I am also grateful to the many Editorial Board members who contributed to making City $\mathcal{E}^{\circ}$ Community such an engaging, scholarly, high-quality publication. Managing Editors Sukriti Issar, Orly Clerge, Omar Pereyra, and Aaron Niznik ably organized the review process and made the lonely job of editing the journal more enjoyable. It has also been a pleasure to work with the staff at Wiley-Blackwell. Finally, thank you to the members of the ASA Section on Community and Urban Sociology for the honor of allowing me to read your work and learn so much from you over the past six years.

To mark the transition, our newest Associate Editor, Karyn Lacy of the University of Michigan, kindly consented to solicit and edit a symposium of peer-reviewed essays on Detroit. The idea for this issue originated with William Tabb, who, with others in Michigan, has been exploring the idea of a Detroit School of urbanism. He recalled that the inaugural 2002 issue of our journal contained a debate over the existence of a Los Angeles School of urbanism, to complement or challenge the hegemonic Chicago School. In 2003, David Halle proposed the existence of a New York School of urbanism as well. Tabb pointed out that, in contrast to the Los Angeles and Chicago Schools' shared emphasis on growth, Detroit-once America's fourth largest city-exemplifies a class of declining cities. Presented with this astute observation, the Editorial Board members gave the green light to a special issue on Detroit.

Although there is considerable urban scholarship on this city, much of it is written by historians, economists, political scientists, and planners, not sociologists. The historians look back at Detroit's industrial heyday, the UAW and African-Americans' struggle for equal rights. The planners look forward in search of a new industry or new governance arrangement that can restore Detroit's grandeur. But perhaps surprisingly, urban sociologists have been reticent. Indeed, the University of Michigan's Detroit Area Study, established in 1951, was never really about Detroit per se. On the 37 th anniversary of the annual survey, conducted to teach graduate students how to do research, Converse and Mayer (1988, p. 9) wrote that if the

Correspondence should be addressed to Hilary Silver, Department of Sociology, Brown University, Providence, RI 02912; Hilary_Silver@brown.edu. 
"objective of providing useful data to the Detroit community [means] taking active steps to get DAS data into the hands of Detroit area officials, influentials, and media people (rather than relying on osmosis), this last purpose, for quite understandable reasons, has simply fallen by the wayside.... DAS has not provided much service to the Detroit community or to the State of Michigan for the deceptively simple reason that it has never been set up institutionally to do so."

Much of what was written in the 37 th year of the DAS still rings true (Clemens et al. 2001). While the area study contributed to the development of survey research in the United States, its emphasis on public opinion and ever changing survey topics restricted its relevance for the study of Detroit, cities in general, or community change.

To be sure, there are exceptions. Some urban sociologists read Detroit through the lens of race relations. Richard Child Hill, for example, collaborated across disciplinary lines to study racial strife in the city (Darden et al. 1987). As affluent white workers achieved suburban homeownership, blacks were excluded from the perimeter of the central city, the basis for Reynolds Farley et al.'s (1978) memorable image of a "Chocolate City, Vanilla Suburbs." Laid beside the Chicago School's paradigmatic concentric zone model, Farley's metaphor for metropolitan area racial segregation compellingly expresses the persistent American Dilemma. He provided a seminal explanation for the continuing segregation in Detroit and other American cities based upon differential racial preferences for integration.

The sociospatial overlay of race and political jurisdiction set Detroit, with an 85 percent black central city, apart from Chicago, LA, New York, and other large, more diverse global cities. Detroit is also an outlier among American cities in suffering from extreme social distress. The city ranks first among the nation's large cities in violent crime, for example. Furthermore, the stark municipal boundaries between whites and blacks have hindered the development of Detroit as an economic or transportation hub for the metropolitan area as a whole. The city's job shortage-there were scarcely 25,000 manufacturing jobs left in 2012 - and an imbalance between available jobs and skills of central city residents, together with the spatial, racial, and skill barriers to distant suburban labor markets, all conspire against African-American employment. This pattern makes Divided Detroit a good model for studying the "spatial mismatch" hypothesis (Farley et al. 2000).

While these attributes distinguish Detroit from other templates, urban sociologists rarely use the city as a basis for generalization. In fact, the sociological study of deindustrialization and urban political economy more generally has largely gone into abeyance, a trend I found disturbing as editor (see Storper 2013, for a notable exception). Urban sociologists may cite Sassen on advanced financial and producer services and Florida on creative industries, but revisiting the scholarship on Detroit reminds us that goods manufacturing was once the foundation of a healthy urban export sector. The Fordist social contract produced a relatively more equal urban income distribution. Those production jobs still exist but now are the base for burgeoning cities in other regions and countries. Detroit represents a growing category of manufacturing-dominated cities losing population, jobs, and tax base. "Detroit's journey from urban heyday to urban crisis has been mirrored in other cities across the nation," so that "the differences between Detroit and other Rust Belt cities are largely a matter of degree, not a matter of kind" (Sugrue 1996, pp. 3, 14). 
Detroit shares similarities with other "shrinking cities" beyond American borders (Mace 2014; Martinez-Fernandez et al. 2011; Wiechmann and Pallagst 2012). Since 1950, Detroit has lost over half of its population, which currently stands at around 700,000. Urban shrinkage, as a consequence of uneven development or creative destruction, is hardly new, and can be found at different scales and long before the deindustrialization and Japanese competition of the 1980s (Bluestone and Harrison 1982; Tabb and Sawers 1984). Nevertheless, Detroit's plight is distinctively American, situated in a decentralized federal system with its complicated race relations, antiunion sentiments, and meager welfare state.

As urban deindustrialization became the stuff of films like "Roger and Me" and as the Voices of Decline (Beauregard 2003) were resounding, depopulation further contributed to Detroit's image of abandonment and vacancy. Ironically, as Jonathan Mijs' photos imply, there is a new hip esthetic of urban decay in which images of Detroit evoke the ruins of ancient cities and similarly attract tourists. The photographs of this "ruins porn" capture both the decrepitude of urban artifacts and the absence of human beings (Herron 1993; Vergara 1999). The pictures express nostalgia for the relics of Fordism and an ambivalence toward postindustrialism. Yet, scholarly criticism of these images often takes the form of gazing at the gazers, pointing out the "crude binaries" photographers use to contrast the decayed city and resilient nature overgrowing the built environment (Millington 2013). Detroit is rendered empty, its inhabitants disappear, calling out for sociologists to make them visible.

Detroit's recent bankruptcy and takeover provide another occasion for sociologists to reconsider the city's "exceptional," "superlative," or "paradigmatic" status (Beauregard 2003; Brenner 2003). The default followed a string of federal and state interventions in the city before the financial crisis of 2007-2008 gradually worked its way down from the global to the local level. As in an earlier wave of municipal defaults during the Great Depression, the Great Recession lingered in cities long after the national recovery began (Neumann 2013). The consequences of Detroit's fiscal crisis are plain to see (Dewar and Thomas 2013; Eisinger 2014). Like disaster survivors, residents live with aspects of a "corrosive community"-limited availability of city services, concerns about public safety, a lack of trust in local and federal government officials, and declining trust in fellow Detroit residents (Wellburn and Turner 2015).

So does Detroit also symbolize default? In many respects, the largest municipal bankruptcy in American history did not resemble most of the other municipal defaults in the country. In fact, municipal bankruptcies are very rare. Since 1954, only 63 local governments in the United States have filed for Chapter 9 bankruptcy protection (Neumann 2013). Not only are those atypical cities small, but their overindebtedness was more likely to reflect poor investments in capital improvements and overly generous but underfunded pension and health care obligations. Yet, like Detroit, most cities emerging from fiscal crisis renegotiated pension arrangements, diversified and raised revenues, and received state assistance, although the fiscally strapped cities of California-Stockton, Vallejo, San Bernardino, even Orange County in the 1990s-found it hard to raise taxes and the state did not intervene. In Michigan, Governor Rick Snyder appointed African-American bankruptcy attorney Kevyn Orr to run Detroit, a move that effectively disenfranchised the city's residents. By November 2014, the receiver had hammered out a court-approved Grand Bargain to restore solvency and home rule. Concessions were made all around, including hopeful gestures of regionalism (Bomey et al. 2014; Rusch 2012). 
In the 1970s, when the state took over New York City's finances to avert default, scholars observed how difficult it is to reconcile legitimation and accumulation crises at once (O'Connor 2001). Fiscal austerity undermines both the possibility of stimulating growth and supporting basic needs. Repeated attempts to revitalize Detroit-the Renaissance Center, stadiums, casinos-have seemed unequal to the task (Darden et al. 1987; Eisinger 2003; Farley et al. 2000). Today, high tech, tourism, and the arts are touted as saviors (Katz 2015; Misra 2015). The great Diego Rivera and Frida Kahlo murals on the walls of the Detroit Institute of Art promise to attract visitors. Similarly, hipsters flocking to Detroit's low-rent neighborhoods are starting galleries, planting urban farms, and installing art, as Mijs' photos here illustrate. Yet, sociologists know, revival is unlikely without participation of the city's longstanding majority of minority residents. Despite high poverty rates of onethird or more, over half the African Americans in Detroit own their homes, and almost two-thirds of the city's businesses are black-owned. They have invested their lives in the city, and are crucial to its success.

In sum, by offering a special issue on Detroit, the journal calls attention to the prototype of divided, deindustrialized, depopulated, and fiscally distressed cities elsewhere. Detroit illustrates the vulnerability of urban economies resting on a sole industry, however mighty it may seem at one time. Detroit provides a counterpoint to the ubiquitous model of the city as growth machine, and draws attention away from the endless search for new leading sectors to the resilience of residents. It reveals the sociological value in interrogating the processes of urban decline, of boom and bust, and in studying those whom hypermobile capital left behind. It symbolizes their resistance to neglect while demonstrating that the solutions to urban distress must often come from beyond the city limits. The articles Karyn Lacy has assembled here provide much material for urban sociologists to contemplate.

\section{REFERENCES}

Beauregard, Robert. 2002. Voices of Decline: The Postwar Fate of US Cities. New York: Routledge.

—. 2003. "City of Superlatives." City E Community 2(3):183-99.

Bluestone, Barry, and Bennett Harrison. 1982. The Deindustrialization of America: Plant Closings, Community Abandonment, and the Dismantling of Basic Industry. New York: Basic.

Bomey, Nathan, John Gallagher, and Mark Stryker. 2014. How Detroit Was Reborn. Detroit: Detroit Free Press. http:/ / www.freep.com/topic/54b59562-6b6b-4b3b-97ad-2b9916a5cdbd/detroit-reborn/

Brenner, Neil. 2003. "Stereotypes, Archetypes, and Prototypes: Three Uses of Superlatives in Contemporary Urban Studies." City E Community 2(3):205-16.

Clemens, Judi, Mick Couper, and Kathy Powers. 2001. The DAS at 50: An Update. Detroit Area Study. Ann Arbor: Survey Research Center, Institute for Social Research, University of Michigan. http://www.icpsr. umich.edu/icpsrweb/ICPSR/series/151

Converse, Jean, and Erica Meyer. 1988. Detroit Area Study, 1952-2001: Celebrating 50 Years. Ann Arbor: Survey Research Center, University of Michigan.

Darden, Joe T., Richard C. Hill, June Thomas, and Richard Thomas. 1987. Detroit: Race and Uneven Development. Philadelphia: Temple University Press.

Dewar, Margaret, and June M. Thomas, eds. 2013. The City after Abandonment. Philadelphia: University of Pennsylvania Press.

Eisinger, Peter. 2003. "Reimagining Detroit." City E Community 2(2):85-99.

—. 2014 "Is Detroit Dead?" Journal of Urban Affairs 36(1):1-12.

Farley, Reynolds, Sheldon Danziger, and Harry J. Holzer. 2000. Detroit Divided. New York: Russell Sage Foundation. 


\section{EDITORIAL}

Farley, Reynolds, Howard Schuman, Suzanne Bianchi, Diane Colasanto, and Shirley Hatchett. 1978. “'Chocolate City, Vanilla Suburbs': Will the Trend toward Racially Separate Communities Continue?” Social Science Research 7:319-44.

Herron, Jerry. 1993. AfterCulture: Detroit and the Humiliation of History. Detroit: Wayne State University.

Katz, Bruce. 2015. "Why Detroit could be the next Silicon Valley (and vice versa)." Brookings Opinion (April 8). http://www.brookings.edu/research/opinions/2015/04/08-detroit-silicon-valley-katz?utm_campaign= Brookings + Brief\&utm_source $=$ hs_email\&utm_medium $=$ email\&utm_content $=16987584 \& \_h s e n c=p 2 A N q t z-$ 9vNv9O5kirFAuIs63-SW6u64Qh_olptb1cU8nav4gksROuhk4SSnFG8mBzu0XoUWC6gM LaJ2p0njE2BkXFL1HgnptFQ\&_hsmi=16987584

Mace, Alan. 2014. "Review of Karina Pallagst, Thorsten Wiechmann and Cristina Martinez-Fernandez (eds.) Shrinking Cities; Margaret Dewar and June Manning Thomas (eds.) The City after Abandonment; and Mark Binelli 2013, The Last Days of Detroit.” International Journal of Urban and Regional Research 38(4):1536-50.

Martinez-Fernandez, Cristina, Ivonne Audirac, Sylvie Fol, and Emmanuele Cunningham-Sabot. 2011. "Shrinking Cities: Urban Challenges of Globalization." International Journal of Urban and Regional Research 36(2): 213-25.

Millington, Nate. 2013. "Post-Industrial Imaginaries: Nature, Representation and Ruin in Detroit, Michigan." International Journal of Urban and Regional Research 37(1):279-96.

Misra, Tanvi. 2015. "The Key to Detroit's 'Bright Future' Goes Way Beyond Car Making." The Atlantic Citylab (April 13). http://www.citylab.com/work/2015/04/the-key-to-detroits-bright-future-goes-way-beyondcar-making/390228/

Neumann, Jeannette. 2013. "US Cities Grapple with Finances: Urban Centers Are Struggling Even as Recovery Takes Shape, Data Show." Wall Street Journal (October 27).

O'Connor, James. 2001 [1970]. The Fiscal Crisis of the State. New Brunswick, NJ: Transaction.

Rusch, Lara. 2012. "Going Regional: The Evolution of an Organizing Strategy in Detroit." City Ẽ Community 11(1):51-73.

Storper, Michael. 2013. Keys to the City: How Economics, Institutions, Social Interaction, and Politics Shape Development. Princeton, NJ: Princeton University Press.

Sugrue, Thomas J. 1996. The Origins of the Urban Crisis: Race and Inequality in Postwar Detroit. Princeton, NJ: Princeton University Press.

Tabb, William, and Larry Sawers, eds. 1984. Sunbelt-Snowbelt: Urban Development and Regional Restructuring. New York: Oxford University Press

Vergara, Camilo José 1999. American Ruins. New York: Monacelli Press.

Wellburn, Jessica, and Kennedy Turner. 2015. "Navigating Economic Decline and Municipal Bankruptcy: Experiences of Working-Class and Middle-Class African Americans in Detroit." Paper to be presented at the Society for the Study of Social Problems Meetings, August 2015.

Wiechmann, Thorsten, and Karina Pallagst. 2012. "Urban Shrinkage in Germany and the USA: A Comparison of Transformation Patterns and Local Strategies." International Journal of Urban and Regional Research 36(2): 261-80. 


\title{
Introduction to the Symposium: Lessons from Detroit
}

\author{
Karyn Lacy* \\ University of Michigan, Ann Arbor
}

In 2014, Detroit was ranked 8th on a list of the country's 10 unhappiest cities. Despite its glorious past, the city is now in deep trouble. Four phenomena contributed to Detroit's placement on the list and set Detroit apart from other large American cities.

First, Detroit has too much land and too few residents. The city stretches over 139 square miles. Detroit is vast. And when a sprawling city loses more than 60 percent of its population, such a mass exodus leads to other problems. In its heyday, Detroit was teeming with people. In 1950, the population was 1.85 million. By 1990, the population had dwindled to 1.2 million. And today, less than a million people, only about 714,000 , are rattling around the city. Detroit is empty. And that means unlike New York or San Francisco, where finding even a tiny square to park your car is an ordeal, in Detroit, land is plentiful and affordable. Developers need not build up, they can spread out. Housing is dirt-cheap. You can buy a house in Detroit for $\$ 25,000$. Today, many blocks in Detroit are home to a single family, living amid a sea of unoccupied, boarded up homes. The city struggles to provide basic services-trash pickup, water, electricity, and police and fire protection-to these isolated homeowners. As a result, Detroit's tax rate is way too high, especially given the sketchy services homeowners receive in return. A core assumption of urban sociology is that cities grow, and growth is a clear signal that a city is thriving. But Detroit is not growing, it is shrinking, posing a new set of challenges for urban scholars and planners. The path forward for the city is much debated among scholars, practitioners, and residents alike, with supporters insisting, "To grow Detroit, you have to shrink Detroit!"

Second, Detroit is stigmatized as a crime ridden, undesirable place to live, in part because of a large black presence: The city is 87 percent black. About 30 percent of residents live in poverty. Only 38 percent of Detroit residents are employed within the city's boundaries, as opposed to the suburbs. There is virtually no real demand for housing apart from investors hoping to flip foreclosed homes and make a quick buck. Gentrification is under way in only a few select neighborhoods. We know from Reynolds Farley's attitudinal studies of neighborhood preferences that most whites are not willing to live in a city like Detroit. The influx of young college graduates, artists, and entrepreneurs is a hopeful sign, but scholars disagree as to whether the presence of these special interest groups will revive Detroit.

Third, Detroit is not known for its amenities. A return migration from the suburbs back to the city is underway in many metropolitan areas around the country as empty nesters, bored with the placid suburban life they once valued back when they had children living

\footnotetext{
*Correspondence should be addressed to Karyn Lacy, Department of Sociology, 500 S State Street, University
} of Michigan, Ann Arbor 48104; krlacy@umich.edu.

City E Community 14:2 June 2015

doi: $10.1111 /$ cico. 12100

(C) 2015 American Sociological Association, 1430 K Street NW, Washington, DC 20005 
at home, now seek walkable communities with a broad selection of restaurants, shopping, and the arts. Edward Glaeser along with his coauthors Jed Kolko and Albert Saiz coined the term "consumer cities" to refer to cities organized around consumption rather than production. Detroit is not that place. It is a one-industry town struggling to remake itself in the wake of the demise of the auto industry.

Finally, and perhaps most importantly to the authors contributing to this symposium, Detroit is a city wrestling with its earlier commitment to decentralization. In 1974, the city established a charter granting community councils the power to weigh in and shape policy, including urban renewal, planning and zoning decisions, crime prevention, and so on. Some argue that, once community councils took root the city government abdicated its responsibility to its citizens. Others welcome the activist agendas of residents and the potential for regional cooperation with Detroit's suburban neighbors. The articles included in this symposium contribute, either directly or indirectly, to the ongoing debate about the long-term impact of decentralization.

Peter Eisinger's article picks up where his 2003 City $\mathcal{E}$ Community article left off. There, Eisinger argued that while political elites and developers attempt to reinvent Detroit by circumventing the city's legacy as an industrial powerhouse characterized by pervasive racial residential segregation, the development models they propose instead-Detroit as a world-class city, as a tourist destination, or as the economic hub for the metropolitan area-are all so quixotic as to be unattainable. To claim that Detroit is poised to become "one of the world's premier cities" in the face of consistent evidence to the contrary, he argued, strains credibility and undermines the public's trust in their elected officials. At the same time, reconstructing Detroit primarily as a destination for tourists or suburbanites risks alienating the city's residents, whose economic and political interests differ substantially from those of outsiders. Eisinger's article in this issue reassesses his 2003 critique in the aftermath of the city's bankruptcy proceedings. Now more than ever, Detroit desperately needs a clear path forward. The three original development models for the city are still in play, but a fourth vision, Detroit as a destination for "urban pioneers," has emerged too as young artists and college graduates migrate to the city, lured by cheap rents and the entrepreneurial spirit that has taken root in the city. The urban pioneers model also includes the expansion of activism among older residents, who take the initiative to organize safety patrols in the absence of a dependable police presence, demolish boarded-up buildings that the city has long ignored, and create car-sharing networks as a substitute for Detroit's inefficient public transportation system. In Urban Fortunes, Logan and Molotch challenged the established view that economic growth is inherently good, suggesting instead that there are significant costs to development, benefitting some groups while oppressing others. In observing that each vision reinforces cleavages-race, class, tenure, and age - rather than uniting all the city's residents and neighborhoods under a common cause, Eisinger illuminates these costs in the Detroit context. Until these conflicts are resolved, Detroit will not recover.

Reynolds Farley's article also takes the 2013 bankruptcy of Detroit as a point of departure. To understand how Detroit became the largest city in the United States to file for bankruptcy, Farley assesses the role of race relative to other explanatory factors. Given Detroit's racially divisive history, many readers may assume that racial division is the primary cause of Detroit's economic collapse. Through historical analysis of the competition for neighborhoods, schools, and employment among black and white residents, Farley 
argues that the path to bankruptcy is rooted in a long history of invidious distinctions by race, but the more immediate factors are deindustrialization and suburbanization.

Some scholars and urban planners believe that regionalism-economic interdependence between Detroit's local government and suburban municipalities-is the best strategy to ensure Detroit's prosperity. Michael Indergaard's article examines the evidence buttressing this claim. While he notes that a few urban-suburban coalitions have formed in recent years, Indergaard questions whether regionalism will live up to its promise. For one thing, he shows that these alliances have been sustained in part through a combination of the carrot-incentives provided by foundations and federal agencies-and the stick-local judges ordering municipalities to cooperate. These alliances do represent a sea change compared to the 1974 Milliken Supreme Court decision upholding marked divisions between the Detroit public school system and its suburban school districts. Today, there is far more cooperation across municipal boundaries. But because they are blinded by the mere formation of these alliances, Indergaard posits that new regionalists underestimate the extent to which familiar divisions such as race and class, as well as emerging divisions such as uneven development, undermine regionalism in the metropolitan area. When the auto industry crashed, Detroit's diverse suburban communities did not experience these economic crises in the same way. In addition, Indergaard finds that the coalition's political elites tend to advance their own interests over and above those of disadvantaged groups. Resources distributed through these metropolitan area coalitions are concentrated in the communities that elites prefer to frequent, such as Detroit's Midtown and Downtown neighborhoods, rather than spread evenly throughout the city, a process that perpetuates inequities within the city's boundaries.

Rebecca Campbell's article coauthored with Jessica Shaw and Giannina Fehler-Cabral explores how and why Detroit's police department managed to amass more than 10,000 untested rape kits. At first blush, the article is not an obvious fit in a special issue focused on whether it is possible to revive Detroit. But, as Jane Addams explained, a city cannot solve major problems until it has a structure in place to ensure the safety and security of residents. With respect to sex offenses, Detroit is not yet safe. In too many U.S. cities, police departments have failed to routinely test rape kits, the most important evidence in the prosecution of individuals accused of rape. The problem is not unique to Detroit, but when combined with demographic data-extreme racial residential segregation, an escalating poverty rate, and in the 1990s, a ranking as the U.S. city with the highest rate of violent crime, Detroit stands out as a particularly egregious case of police negligence and misconduct regarding the prosecution of sex crimes. Rather than testing the rape kits, police officers stacked them in a storage room. Through in-depth interviews and analysis of memos circulated between police officers and prosecutors, Campbell, Shaw, and Fehler-Cabral find that police officers failed to take accusations of rape seriously in a city where victims are disproportionately black and poor. Both groups are less likely to be perceived as credible when they report a crime. The authors find police officers reasoned in their reports that victims were not really raped, invoking deep-seated stereotypes of black women as sexually available. Officers tended to assign rape victims the offensive label of "prostitute" and, operating under the equally misguided belief that prostitutes cannot be raped, declined to process their rape kits. Teenage victims were also dismissed as liars, as kids concocting stories about having been raped to avoid getting into trouble at home. Although the nation is currently fixated on Ferguson and Staten Island, notorious examples of police misconduct worthy of our attention, the authors show that police 
recalcitrance and unwillingness to admit wrongdoing are serious problems in sexual assault cases too. Detroit cannot prosper so long as the city's streets are unsafe. The city is only just beginning to resolve its rape kits problem after finally reversing course on the procedure for processing this evidence.

Laura Reese's article evaluates Detroit's inability to solve what has quickly become an enormous stray animal population problem. Reese observes that while scholars have studied the ways in which urbanization encroaches on the natural habitats of a region's wildlife, little is known about the conditions under which wild animals invade the central city, an inevitable outcome of urban sprawl. Detroit's economic collapse contributed to the sharp rise in stray animals, as unemployed and underemployed residents tend to abandon their pets. But Reese argues a struggling economy is not the only factor, indeed, it is not the primary factor. Instead, Detroit's decentralized governmental system is the root cause of the stray animal problem. Detroit's political leadership has not organized consistently or successfully to control a burgeoning stray animal population, a crisis affecting poor neighborhoods disproportionately. The Detroit Animal Control agency has a total of three licensed animal control officers. As a result, nonprofits have emerged to do the hard work that the city cannot. However, Detroit is isolated from the metropolitan area's animal welfare agencies. Through analysis of the service provisions of animal welfare organizations, Reese finds little evidence in support of regionalism. Detroit's leadership has minimal ties to suburban animal welfare organizations. These agencies, composed primarily of white women volunteers, share resources and volunteers among themselves, but they report minimal cooperation with Detroit's animal shelters.

Together these articles show that there is little consensus among residents, public officials, and community leaders about the best path forward for Detroit. The authors contributing to this issue hint that Detroit can be saved, but clearly any intervention should protect the interests of all of the city's residents. 


\title{
The Bankruptcy of Detroit: What Role did Race Play?
}

\author{
Reynolds Farley* \\ University of Michigan at Michigan
}

\begin{abstract}
Perhaps no city in the United States has a longer and more vibrant history of racial conflict than Detroit. It is the only city where federal troops have been dispatched to the streets four times to put down racial bloodshed. By the 1990s, Detroit was the quintessential "Chocolate City-Vanilla Suburbs" metropolis. In 2013, Detroit became the largest city to enter bankruptcy. It is an oversimplification and inaccurate to argue that racial conflict and segregation caused the bankruptcy of Detroit. But racial issues were deeply intertwined with fundamental population shifts and employment changes that together diminished the tax base of the city. Consideration is also given to the role continuing racial disparity will play in the future of Detroit after bankruptcy.
\end{abstract}

\section{INTRODUCTION}

The city of Detroit ran out of funds to pay its bills in early 2013. Emergency Manager Kevyn Orr, with the approval of Michigan Governor Snyder, sought and received bankruptcy protection from the federal court and Detroit became the largest city to enter bankruptcy. This paper explores the role that racial conflict played in the fiscal collapse of what was the nation's fourth largest city.

In June 1967 racial violence in Newark led to 26 deaths and, the next month, rioting in Detroit killed 43. President Johnson appointed Illinois Governor Kerner to chair a commission to explain the causes of urban racial violence. That Commission emphasized the grievances of blacks in big cities-segregated housing, discrimination in employment, poor schools, and frequent police violence including the questionable shooting of numerous African American men. Examining trends, the Kerner Commission saw increasing racial disparities and concluded, "Our nation is moving toward two societies, one black-one white-separate and unequal" (National Advisory Commission on Civil Disorders 1968, 407). They described a future in which central cities would be populated by low-income minorities, while a more prosperous and overwhelmingly white population resided in the suburbs.

Census 2000 confirmed the Kerner Commission prediction, at least with regard to Detroit. African Americans madeup 82 percent of the city's population but in the threecounty suburban ring, 86 percent were white. ${ }^{1}$ During the Civil Rights decade riots occurred in many cities in the Northeast and Midwest. And, in these regions, central cities and their suburbs typically differ in racial composition. But the city of Detroit is unique.

*Correspondence should be addressed to Reynolds Farley, Population Studies Center, University of Michigan, 426 Thompson; Ann Arbor, 48109; renf@umich.edu.

City $\mathcal{E}^{\circ}$ Community 14:2 June 2015

doi: $10.1111 /$ cico. 12106

(C) 2015 American Sociological Association, 1430 K Street NW, Washington, DC 20005 
In 2013, there were 77 cities of 250,000 or more. Detroit was the most racially homogeneous. It had the highest poverty rate-41 percent of all residents-and the greatest percentage of children impoverished: 59 percent. It had the lowest median household income and only one large city-Santa Ana, California-had a smaller percentage of adults with college degrees. It was 13 percent in Detroit. Owner-occupied homes in Detroit had the lowest median value- $\$ 24800$ - and Detroit was at the top of the list with regard to vacant homes: 31 percent.

Can Detroit's bankruptcy be explained most cogently by the racial hostility that propelled an exodus of prosperous white residents from the city to the segregated suburbs? Didn't this cause the city's tax base to collapse as the city followed the trajectory described by the Kerner Report and became home to the minority population with low incomes and limited educations? The explanation is more complicated than just race or segregation. Understanding why Detroit descended into bankruptcy requires tracing the historical antecedent of the crisis. Most every policy development and major political decision in the Detroit area after World War II was strongly influenced by racial conflict. And a variety of governmental decisions and macroeconomic trends had tremendously different consequences for blacks and whites.

The first section of this paper describes the bankruptcy process and its resolution. Then information is presented about the specific causes of the bankruptcy. Next there is a discussion of the role race played in those causes. Finally, comments are presented about the future of Detroit with a focus upon how race is linked to recent changes in employment and residence.

\section{DETROIT: THE BANKRUPTCY PROCEEDINGS AND THE RESOLUTION}

Michigan's legislature enacted an Emergency Financial Manager law in 1988 to mitigate the financial problems of troubled cities and school districts. Should they be approaching insolvency, the state treasurer was to alert the governor. If the governor agreed, the treasurer was to work out a consent agreement in which the local government would promise to balance its books, primarily by reducing wages, firing workers, and deferring payments of its debts. If little progress were made, the treasurer again alerted the governor, who had the authority to appoint an Emergency Manager. This person would have almost total control of a local government. He or she could abrogate contracts, reduce employment, cut wages, sell municipal assets, and eliminate expenditures but was obligated to pay bond holders and could recommend but not impose new taxes.

In 2012, the state treasurer notified Governor Snyder that the city of Detroit was on the edge of insolvency. The city entered into a consent agreement. City employees were laid off, wages cut to 10 percent, and services reduced. In early 2013, the treasurer reported that Detroit was not making sufficient progress in slashing spending. Governor Snyder concurred and in March 2013, appointed Kevyn Orr to run the city of Detroit. He is an African American bankruptcy lawyer who played important roles in the federal government's support of the bankrupt Chrysler Corporation. He holds two degrees from the University of Michigan and attended law school there with Governor Snyder as a classmate. Given the history of racial conflict, it would have been provocative had the governor turned over control of Detroit to a white man or woman. 
Orr examined the finances and concluded that the only feasible solution required reducing payments to all who were owed monies. Governor Snyder agreed and Orr requested bankruptcy so that Detroit could be freed from its legal obligations, including those to bond holders and pensioners. Federal bankruptcy Judge Stephens Rhodes held hearings. Orr stressed the city's lack of resources, its indebtedness, and its inability to pay for usual city services. Creditors-especially bond holders and pensioners-argued that Orr overestimated debts and underestimated assets that might be sold, especially paintings in the Detroit Institute of Art. After evaluating these arguments, Judge Rhodes approved bankruptcy in the summer of 2013.

Federal Chapter 9 bankruptcy is designed for local governments and assumes that cities will continue to function during and after their insolvency. The process calls for the bankrupt municipality to negotiate with debtors to reach settlements. If agreements are not reached, the bankruptcy judge "crams down" a settlement. But assets and revenue streams are to be maintained so that the city can provide minimal services. Bankruptcy Judge Rhodes appointed Gerald Rosen, senior federal judge for the Eastern District of Michigan, as the lead negotiator.

At the start, many assumed that Detroit had numerous valuable assets that might be sold to pay bond holders, pensioners, and other debts: a water and sewerage system that served southeast Michigan, a system for distributing electricity, more than 100 parks, and three museums in addition to the nation's sixth largest art gallery. It soon became clear that the only assets that could be sold quickly for cash were the masterpieces in the Detroit Institute of Art. That organization faced a financial crisis in 1919. Detroit at that time was prosperous so the trustees of the art gallery gave their holdings to the city in return for a generous annual stipend. And the city, in the 1920s, not only supported the construction of their magnificent gallery but paid for the purchase of many European art works.

The most vocal parties in the negotiations were spokespersons for bond holders and for the two funds that provided pensions for municipal employees: 9,000 currently employed and more than 20,000 retired. Retirees asserted that Michigan's constitution required that pensions must be paid even if a city were bankrupt but Emergency Manager Orr challenged their view and suggested that it might be necessary to cut pensions 30 percent or more.

At this point, the lead negotiator, Judge Rosen, orchestrated a "Grand Bargain" designed to simultaneously protect pensions and save the art. Using his influence, he arranged an agreement whereby prosperous foundations linked to Detroit-Ford, Kellogg, Kresge, Mott, and Skillman-provided \$366 million, the state of Michigan provided \$350 million, while the Detroit Institute of Art agreed to raise $\$ 100$ million over 20 years. These monies were placed in pension trust funds, while the art and the Gallery were transferred to a non-profit organization. The pensions of uniformed officers will be paid at 100 percent, while other city workers will be paid at 95 percent although adjustments for inflation have been reduced or eliminated.

Emergency Manager Orr's final Plan of Adjustment called for reducing the city's debt from about to about $\$ 19$ billion to $\$ 7$ billion, while reserving $\$ 1.4$ billion for investments in the city in the next decade. These will largely be devoted to higher wages and more resources including personnel for the fire and police departments, new computers and information technology, and the demolition or deconstruction of many of the 85,000 blighted and abandoned structures that line the streets. 
As the bankruptcy trial proceeded, lawyers for the firms that insured bonds feared they might get as little as six cents on the dollar. They negotiated with Kevyn Orr, who agreed to let those bond insurers operate-but not own-revenue-generating city assets including the international tunnel and Downtown parking structures. In addition, those insurers will be able to purchase, at a discount, valuable city-owned parcels, including choice ones near the riverfront that may be developed for commercial and residential use. Presumably, these insurers will recoup their losses by investing in revenue-generating real estate in Detroit, investments that will eventually increase the city's tax base. Judge Rhodes accepted the settlements negotiated by Kevyn Orr and in December 2014 Detroit's bankruptcy ended. Kevyn Orr concluded his service as Emergency Manager and elected officials-Mayor Duggan and Common Council-resumed running the city. Detroit will differ from other Michigan places since a state-appointed Financial Review Commission will monitor or control the city's spending and borrowing.

\section{THE CAUSES OF DETROIT'S BANKRUPTCY}

\section{THE DISAPPEARANCE OF THE TAX BASE AFTER WORLD WAR II}

There are three causes of Detroit's fiscal crisis. Bankruptcy court hearings and the detailed reports of Kevyn Orr revealed the fundamental reason for the crisis: the collapse of its tax base in the post-World War era. This may be easily summarized:

- From 1950 to 2013, the population fell by 63 percent

- From 1950 to 2013, the number of occupied homes and apartments fell by 49 percent

- From 1950 to 2013, the number of Detroit residents holding a job declined by 74 percent

- From 1947 to 2012 , the number of manufacturing firms in the city fell by 88 percent

- From 1947 to 2012, the number of manufacturing workers employed in the city fell by 95 percent

- From 1947 to 2007 , the number of retail stores fell by 88 percent

- From 1947 to 2007, the number of wholesale businesses fell by 88 percent

The recession that began in 2008 explains the timing of the bankruptcy. Between 2007 and 2013, per capita income in the city dropped by 13 percent in constant dollars, the number of employed residents fell by 18 percent, the assessed value of residential property by 47 percent, while the poverty rate increased from 34 to 41 percent. By 2011, property taxes were being paid on only 53 percent of taxable properties (Citizens Research Council of Michigan 2013). In addition, the Census 2010 count and a change by the legislature in how Michigan's sales taxes receipts were distributed to local governments reduced Detroit's revenue flow from the state by 7 percent of the city's General Fund Budget (Oosting 2014). The disappearance of its tax base is the key reason for the bankruptcy of Detroit. There are, however, other contributing factors. 


\section{A CONTRIBUTING CAUSE: MICHIGAN'S DYSFUNCTIONAL SYSTEM OF LOCAL GOVERNMENT}

Michigan in 1909 adopted a "Home Rule" law that may have been appropriate for the pre-automobile era when people lived, worked, and shopped in their own municipality. The Home Rule Law made it easy for townships, villages, and other population clusters to form their own highly independent governments, largely free of state oversight. It gave them great power to tax, assume debts, and manage their own responsibilities such as zoning, policing, fire protection, and economic development. It provided localities with no incentives to cooperate with neighboring governments. The Home Rule Law made annexations and mergers extremely difficult or impossible. The Home Rule system vests great authority in local governments as independent entities responsible for their own welfare.

Local governance became a metropolitan issue following World War II. By the 1960s, Detroit was surrounded by 124 suburban governments. Residents traveled throughout the metropolis daily with little attention to corporate limits. A public transportation system and parks, you might think, would be designed to serve city and suburban residents. Economic development, land use, and the environment are certainly dealt with best at the metropolitan level but that does not happen in Michigan. Every city addresses these issues independently thus the Home Rule law precludes regional solutions to regional problems.

By the 1950s, urban officials and planners across the nation understood the rapid growth of the suburbs and the diminishing resources of older cities. In numerous states, legislatures allowed cities to annex outlying land so that their tax base could increase. Detroit has annexed no land since the 1920 s, so the city missed out on the tremendous population and economic growth that occurred in southeastern Michigan from 1946 through the 1970s. Since 1950, 13 cities have surpassed Detroit in population size, primarily because they annexed their suburbs. If Detroit had annexed as much outlying area as Columbus or Indianapolis, its population would today probably be close to 2 million now rather than the 688,000 estimated for 2013. And the city would not be bankrupt. Similarly, if the state government, in the 1950s, had realized that economic development, transportation, environmental protection, education, and parks were regional issues and established authorities whose scope spanned an entire metropolis, Detroit would not have entered bankruptcy.

\section{CONTRIBUTING CAUSES: THE MISJUDGMENTS AND CORRUPTION OF DETROIT'S LEADERS}

The city's bankruptcy was hastened by the decisions leaders made and by their corruption. Recognizing the disappearance of the tax base, they initiated new taxes and raised traditional ones, making the city a less attractive place to live or do business. Detroit was the first Michigan municipality to impose an income tax; it is the only Michigan city with a 5 percent tax on all utility bills. Property tax rates were raised to the maximum level permitted by state law and numerous other levies were imposed so Detroit continues to have the highest taxes in the state. And it is the only Michigan city to obtain a large fraction of its general funds revenue from casino gambling. 
Given the financial crisis, city leaders greatly reduced municipal services. Similar to other Rust Belt local governments, city officials were unable to offer municipal workers large wage increases. In lieu of raises, they promised extensive retirement and fringe benefits, promises that could not be kept as the tax base shrunk. As revenues declined, the city borrowed tremendous sums to maintain minimal services using traditional and innovative financial instruments. Once again, it turned out that the city lacked the resources to pay those obligations.

The city gained a reputation for poorly administering its basic functions. The water and sewerage system was superintended by federal judges from 1977 to 2013 . Because of civil rights violations, the Department of Justice supervised the Police department for 14 years after 2000. The federal government took control of city's Housing Commission in 2005 due to financial mismanagement. The state of Michigan took over the city school system in 1999, returned it to local control in 2005 and then took it over again in 2008. The governor of Michigan, not an elected board, continues to superintend the city's schools.

Numerous elected and appointed officials have gone to jail. Phillip Hart, Chief of Police in the Coleman Young administration, was convicted of stealing city funds and sentenced to 10 years. Kwame Kilpatrick, mayor from 2003 to 2008, briefly benefited from a "Pay to Play" scheme. After 6 years of litigation, 34 were convicted and Mayor Kilpatrick is now serving a 28-year sentence (Schaefer 2013; Yaccino 2013). Monica Conyers, President Pro-Tem of Detroit's Common Council in 2008 and 2009, was sentenced to 37 months for her role in steering municipal contracts (White 2010). Officials administering the city's pension system were convicted of looting funds (Snell 2014).

Detroit's bankruptcy is not the result of the venal behavior of its officials. Given the collapse of the tax base, perhaps no mayor could have produced the miracle needed to prevent bankruptcy. Nevertheless, Detroit officials contributed to the image that the city could not manage its own finances and that state and federal funds flowing to Detroit were often misspent.

\section{RACE AND ITS LINK TO THE FACTORS THAT LED TO THE CITY'S BANKRUPTCY}

\section{RACIAL COMPETITION FOR CONTROL OF THE CITY'S NEIGHBORHOODS, SCHOOLS, JOBS, AND THE GOVERNMENT}

This section seeks to answer the question of how racial conflict was intertwined with the three causes of Detroit's bankruptcy. Detroit was riven by two major conflicts for much of the twentieth century: whites versus black and labor versus management. Accommodations were worked out after World War II that muted the hostility but they eventually proved flawed and, thereby, contributed to the bankruptcy of Detroit. It is the complicated interaction of racial issues with demographic and economic change that both explains the bankruptcy and will determine whether the city prospers or falters in the future.

Detroit became an industrial colossus in the decades following the Civil War. Thanks to its location near Michigan's pine forests and on the river where iron ore, coal, and other minerals were readily shipped, Detroit became a leading manufacturing center by the 1890s. Skilled craftsmen turned out what would be the component parts for vehicles. 
By 1901, Ransom Olds was assembling cars in substantial quantities in Detroit, and in 1908, Henry Ford designed the Model T, revolutionizing how Americans lived their lives. Ford perfected the assembly line in 1914, and, immediately thereafter, huge factories were built, employing thousands of workers to build millions of vehicles. Detroit became the Motor Capital of the world.

The growth of manufacturing explains the migration of African Americans to Detroit. People came to take the factory jobs, first from Canada and the Midwest, later from Germany and Eastern Europe. The German Navy in World War I cut the flow of immigrants from Europe, but Detroit's factories were converted to munitions production so the need for labor increased. The American South became the source of workers and, for the first time, the black population began to grow rapidly. European immigrants were quite rapidly assimilated in Detroit but African Americans faced many more challenges. Beginning at the time of World War I and continuing for six decades, many whites in Detroit sought to preserve the racial homogeneity of their neighborhoods, the schools their children attended, their advantage in employment, and their control of the city's government, especially the police. The vehicle firms, however, found it difficult to recruit and retain workers so they hired many blacks and paid them generously. Indeed, auto industry jobs were among the nation's highest paying blue collar jobs. This created a prosperous black working class population in Detroit, a population that attracted black professionals from across the nation who served the needs of other African Americans. By 1950, Detroit had the nation's most prosperous black community as measured by earnings and family income.

A persistently contentious-and sometimes violent-issue was whether blacks and whites could live on the same blocks. The most publicized civil rights litigation of the 1920 s concerned Dr. Ossian Sweet, a black doctor who purchased a home in a white neighborhood. When he moved into his property, a crowd of hostile whites surrounded it. Feeling threatened and convinced that the police would not protect his family, Dr. Sweet's brother fired into the crowd, killing one man. At that point the police arrested Dr. Sweet and his colleagues and they were charged with murder. Clarence Darrow won acquittal for Dr. Sweet and his brother, thereby upholding the principle that a black man could defend his home when it was about to be destroyed (Boyle 2004; Vine 2004). Detroit was one of many northern cities where a more peaceful way of preserving the purity of white neighborhoods spread rapidly after World War I: the use of restrictive covenants (Vose 1959). And then, with the development of new federal housing policies in the 1930s, the practice of redlining maintained thorough segregation.

Issues of housing were prominent in Detroit during World War II when the black and white populations grew rapidly as the city became the Arsenal of Democracy. The first racial violence of World War II occurred in Detroit in 1942 when blacks tried to move into the Sojourner Truth Homes-housing that had been designed for blacks but was located not far from white neighborhoods (Capeci 1984; Capeci and Wilkerson 1991). Whites kept them out for several months but a forceful police and military presence eventually allowed African Americans to enter.

Sugrue's (1998, Part 3) description of Detroit after World War II portrays consistent neighborhood racial conflict. The migration of southern blacks and whites continued after World War II since high paying industrial jobs were plentiful. Whites recognized that an increasingly prosperous black population would seek housing outside the dense east and west side ghettos where they were confined. In litigation arising from Detroit, 
the Supreme Court ruled in 1948 that restrictive covenants could not be enforced by courts (Brooks and Rose 2013). Conflicts raged in many Detroit neighborhoods. Whites tried to keep blacks out but African Americans sought housing commensurate with their status. Block busting occurred frequently as brokers scared whites into quick sales and then flipped homes to blacks for higher prices.

Litigation about the integration of public schools in Detroit dates from 1869 (Baugh 2011). In the 1970s, the NAACP successfully convinced the local federal court that Detroit school officials deliberately segregated students creating separate and unequal schools. To comply with the mandates of the Brown decision (1954), the court ordered that black students be bused to formerly white schools in the suburbs while suburban white students would be bused to formerly black city schools. The Supreme Court overturned that policy but the city's schools then adopted policies that bused those few white students who remained in Detroit (Wolf 1981; Baugh 2011).

Employment was another area of long-standing bitter conflict. Although hired in large numbers, most employers set limits on the jobs that blacks could fill. In the 1930s, for example, the school system was willing to hire blacks to teach at elementary schools but it took pressure from civil rights groups to get blacks hired at secondary schools. By threatening a March on Washington in 1941 as the nation prepared for World War II, A. Phillip Randolph pressured President Roosevelt to issue Executive Order \#8802. This encompassing and strong order mandated that blacks and whites working for firms producing munitions be paid identically and treated similarly with regard to employment. Blacks in Detroit saw this as an opportunity to move up the job ladder, but white workers strongly resisted those efforts. Detroit became the home to "Hate Strikes"-whites walking off the job if blacks were promoted into better jobs, blacks walking off the job if they were not treated the same as whites (Meier and Rudwick 1979). A "Hate Strike" in early June 1943-one that saw 25,000 white Packard workers walk off the job because three blacks were promoted-was one of many factors contributing to the largest racial riot of World War II (Baime 2014, chapter 26). It began on June 20, 1943, on Belle Isle as young blacks and whites fought with each other. It ended the next evening when President Roosevelt dispatched the Fifth Army to forcefully put down racial violence, but 34 Detroit residents died (Shogan and Craig 1964).

Whites shared the widespread perception that black men were dangerous, so they assumed that the stern policing was the ideal strategy to suppress black crime. For decades, the NAACP in Detroit sought to end what they perceived as police violence against young blacks. There were several interpretations of the urban violence of the 1960s. While some African Americans described the riots as rebellions seeking to overturn white oppression, a common view among many whites and some blacks in Detroit after the 1967 violence was that it was a commodity riot. They assumed that lax policing gave criminally prone young blacks the opportunity to loot. Shortly after the 1967 bloodshed, Detroit Police Commissioner Nichols established a police unit called STRESS (Stop Robberies Enjoy Safe Streets) and gave it instructions to crack down on street crime using whatever force was needed. In a 2-year span, STRESS officers killed 22 residents, 17 of them young black men (Spreen and Holloway 2005, 122). In the black community, STRESS was known as the Killer Squad.

Some whites and organizations in Detroit worked diligently for racial accommodation. The local Democratic Party nominated and appointed many blacks. United Auto Workers (UAW) leaders supported civil rights, and that union was the leading financial backer 

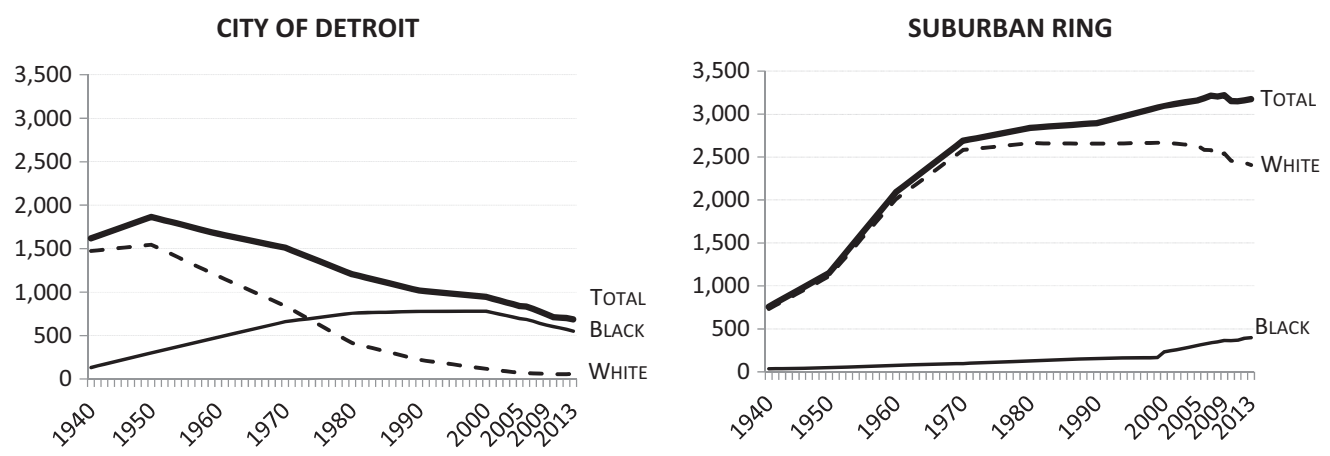

FIG. 1. Population of the City of Detroit and the three-county suburban ring: 1940 to 2013.

of the 1963 March on Washington. The Catholic diocese encouraged Detroit pastors to welcome the blacks who moved into their neighborhoods. But those voices were hardly heard.

The solution to persistent racial conflict was the withdrawal of most whites from the city-the American Apartheid solution (Massey and Denton 1993). Federal housing policies encouraged the invasion of the "crabgrass frontier" after World War II (Jackson 1967). Attractive new homes in the suburbs offered more amenities than the workingmen's home built in the city and could be purchased for little down and low monthly payments. But the suburbs were, with few exceptions, open only to white residents. Detroit suburbs adopted a variety of informal and formal practices to convey to blacks that they were not welcome (Freund 2007). Dearborn mayor Orville Hubbard became a national symbol of suburban resistance to integration (Good 1989). The election of Coleman Young as the first black mayor of Detroit in 1973 symbolized a shift in which race ran Detroit. As Figure 1 shows, the number of white residents in Detroit dropped from 1.5 million in 1950 to 117,000 a half century later. Whites comprised 83 percent of the residents at the start of that span, 12 percent at the end. No large city in the country became as overwhelmingly black in its composition. In no other city was "Black Power" so extensive since African Americans held most elected and many appointed positions in Detroit. And in no metropolitan area was the city-suburban disparity in racial composition as extreme as in Detroit. Federal housing policies after World War II were not designed to maximize racial segregation. They were Keynesian strategies to avert a resumption of the Great Depression. But in Detroit, they and the Federal Government's building of the interstate highway system in the 1960s and 1970s contributed to the demographic processes that made metropolitan Detroit the most segregated metropolis at the end of the twentieth century.

The exodus of whites from the city led to a tremendous decline in the city's tax base. Is it accurate, then, to conclude that the racial hostility that led to white suburbanization caused the bankruptcy? I think it is not. If there had been no black-white conflict over neighborhoods in the Detroit area, the white population would have declined, perhaps quite rapidly. Much of Detroit's housing stock consists of workingmen's homes built before the Depression (Desjarlais 2008). They lack the amenities that middle class families desire - a bedroom for each child, a modern kitchen, efficient heating and cooling, a two-car garage, and considerable space around the home. The federal housing programs 
facilitated the construction of such homes in the suburbs after 1950s so Detroit's white residents moved out in substantial numbers. Quite likely, if race had not been such a divisive issue, Detroit's population would have declined less rapidly and a somewhat larger share of the area's middle class residents would live in the city. Perhaps, this would have prevented bankruptcy. But if racial attitudes had been different and if the Open Housing Act prohibiting racial discrimination by real estate brokers had gone on the books in 1947 rather than 1968, the middle class black population would have joined whites in search for the higher quality housing built in the ring.

There is an additional way in which residential segregation hastened the city's bankruptcy. By the time Coleman Young became Detroit's first African American mayor in 1974, the city-suburban divide was a white-black divide. Suburban officials, for the most part, distrusted any mutual agreements with the city (Young and Wheeler 1994, 283285). Oakland County Executive Brooks Patterson became a popular spokesperson for the view that the interests of the suburbs conflicted with those of the city so he advocated no cooperation (Williams 2014). City officials in Detroit often expressed contempt for the suburbs and generated the fear that white suburbanites and out-state interests were conniving to take over the city's most valuable assets. The race card was played in most mayoralty elections as one of the African American candidates would accuse the other of accepting too many campaign funds from the "white suburban interests." The strong tradition of local Home Rule in Michigan produced a situation in which there are few examples of cities and their suburbs cooperating to resolve metropolitan issues. But the city-suburban racial disparity in the Detroit region was especially intense. A metropolitan park system developed after World War II but the city's parks were not included. And the city and the suburbs, to this day, maintain separate and uncoordinated bus systems.

\section{LABOR-MANAGEMENT CONFLICT AND ITS RESOLUTION}

The history of labor-management conflict in Detroit rivals that of racial conflict. As Detroit became an industrial metropolis, a vibrant union movement attempted to organize the workers with little success. That changed after Congress, in 1935, passed the Wagner Act requiring firms to recognize unions. Managements resisted and contended the law was unconstitutional, but in 1937, vehicle sales increased sharply after the 7-year Depression slump. Management had the opportunity to finally generate profits, but auto workers saw an opportunity to gain recognition for their union. The Detroit area was home to highly effective "sit-down strikes." Workers went into the plant, sat down, and refused to either work or leave. General Motors and Chrysler, seeing a loss of profits and fearing possible damage to their plants, quickly recognized the United Auto Workers (UAW) union, but Ford held out (Fine 1969). The auto firms had a history of hiring many African Americans and the UAW, presumably fearing that blacks would be used as strike breakers, welcomed them as members. In 1941, the UAW successfully led a strike of many white workers at Ford's River Rouge plant. Harry Bennett, who managed Ford's operations at the time, attempted to lock black workers inside the plant and lock white workers out. He assumed that he could recruit Detroit blacks to replace the striking white workers but relatively few blacks were willing to cross the picket line. This was a key turning point since Detroit blacks allied their interests with working class whites. Subject to 
great pressure from the state and federal government because of the lead-up to World War II, Ford reluctantly recognized the UAW.

During that war, federal regulations discouraged strikes in plants turning out munitions, but as soon as the war ended, the UAW struck strategic locations throughout the vehicle industry, effectively interrupting production at a time when the demand for cars was great. After years of conflict, the three large producers signed the "Treaty of Detroit" in 1950. It provided auto workers with many of the benefits we associate with the Scandinavian countries: wages indexed for inflation, employer-paid health care insurance for the worker and his/her family, generous and early retirement benefits, long-term unemployment insurance, and extended vacations. The "Treaty of Detroit" muted labormanagement conflict and set a precedent for wages and benefits for employers throughout the Rust Belt (Lichtenstein 1995). It certainly established a prosperous blue-collar middle class and also insured great prosperity for the vehicle producers and their suppliers since, for a score of years, they passed along higher labor costs to their customers. And in the Detroit area, this labor agreement meant that many whites in the city could afford suburban housing, while blacks could afford the homes of departing whites. Fortunately for whites, homes in the suburbs generally appreciated in value until the recent recession while the value of those blacks purchased in the city typically declined.

The large vehicle firms did not leave Detroit for racial reasons. Rather, the plants in the city dated from the World War I era so they were antiquated. The suburban ringnot the city-had empty land available for efficient one-level plants. Wholesaling left Detroit, not for racial reasons, but rather because the National Defense Highway system provided access to and space for modern one-story warehouses that could not be built in the densely settled city. The presence of racial conflict in the city and the perception that the crime rate soared after 1973 when the control of the city's government passed from whites to blacks accelerated the out-movement of white residents. But, had the city been racially homogeneous after World War II, employment in the city would have plummeted.

\section{DETROIT AFTER BANKRUPTCY: THE ROLE OF RACE IN THE FUTURE OF THE GITY}

A productive way to consider the city's future is to focus upon two topics: employment and revenues.

\section{JOBS AND CAPITAL INVESTMENTS IN DETROIT}

The future of metropolitan Detroit and the city depends, more than anything else, upon employment trends. The number of employed Detroit residents reached a recent peak of 368,000 in 1999 , fell to a low of 274,000 in 2011 and then rebounded a bit to 285,000 in late 2014 (U. S. Bureau of Labor Statistics 2014a). There are optimistic signs because major employers are making capital investments. Marathon Oil spent \$2.2 million to modernize their refinery in southwest Detroit and is now the largest payer of property taxes. The vehicle manufacturers invested substantially in retooling their plants in and around Detroit. General Motors, since its bankruptcy, has invested more than $\$ 350$ million in its Hamtramck Assembly plant that straddles the city's border. Fiat-Chrysler updated their 
Jefferson North plant-in Detroit-where 35,000 Jeep Cherokees and Dodge Durangos are produced every month. Ford Motor not only renovated their Dearborn Assembly plant for F-150 production, but also their nearby Flat Rock Plant and Wayne factories. The two basic steel mills in the Detroit area have been modernized and are now more efficient than in the past. A neighborhood of dilapidated homes on the east side was razed in the early 1990s to create the 290-acre I-94 Industrial Park. It stood empty for 20 years but, in 2015, plans were announced to build an auto parts plant on 40 acres bringing new jobs to the city (Martinez 2015). America's iconic industrial ruin-the huge Packard Plant on East Grand Boulevard that has been idle since 1955—was purchased by a real estate investor and a decade-long renovation program is underway (Aguilar 2014).

The Detroit Medical Center, in 2010, announced an \$800 million dollar expansion of its huge medical campus near Downtown. Two weeks later, Henry Ford Medical Center announced an expenditure of $\$ 500$ million to erect a new hospital campus in the city's New Center area. Wayne State University, home of the nation's largest medical school, continues to expand its facilities. Blue Cross-Blue Shield transferred several thousand employees from suburban offices to the Renaissance Center, and in 2012, for the first time, that edifice was fully utilized.

Dan Gilbert's Quicken Loans firm shifted its employees from the suburbs to the central business district of Detroit. He then purchased or took options on 60 Downtown buildings containing more than 8 million square feet of space (Gallagher 2014). He intends to attract firms and entrepreneurs developing the information technologies that will change how we drive our vehicles. More so than in the past, numerous programs promote innovation, thanks to several foundation-funded initiative and many tax initiatives. A variety of other organizations seek to make the city of Detroit a hub for entrepreneurial activities linked to manufacturing.

New baseball and football stadia and three casinos with their hotels enliven what had been a moribund and dangerous Downtown Detroit. The Ilitch family is leading a project to erect a strikingly different hockey arena for their successful Red Wings. By 2017, it will be the central attraction in an innovative "urban village" with apartments, condos, retail stores, and office space. Detroit is distinguished from other Rust Belt cities in the way in which its major foundations and most prosperous individuals invested monies to create economic opportunities, primarily in the Downtown-Midtown area

Kurt Metzger, who headed data driven Detroit for years, describes Detroit as a "Tale of Two Cities." Downtown and Midtown Detroit are prospering with steady increases in employment and some residential growth. They may compare favorably with economically successful areas in other Rust Belt cities. But the other Detroit is made up of the declining neighborhoods that have been losing population for generations.

\section{THE FUTURE OF DETROIT NEIGHBORHOODS}

Cities' revenues depend upon the number of residents and their ability to pay taxes. Shortly after Mayor Duggan took office in 2014, he encouraged Detroit residents to stay and suggested that they should judge his administration by whether his policies stabilized the population (Dolan 2014). Retaining current residents and attracting new ones depends upon having appealing neighborhoods. There are elegant neighborhoods in Detroit-Indian Village, Palmer Woods, and Sherwood Forest-that never went into 
decline. Attractive architect-designed homes may be purchased for reasonable sums. Presumably, their future is secure. Other neighborhoods with architecturally significant homes were once on the cusp of sliding into decline but their residents and investors turned around their trajectory, including Corktown, West Village and Woodbridge. They are now charming neighborhoods, appealing to younger professionals who prefer city living. And they are located close to the areas of employment growth. Detroit has a few other neighborhoods with a potentially attractive housing stock that may join the list of secure and stable residential areas including the North End, Virginia Park, and the Atkinson Avenue Historic District.

Those neighborhoods are exceptions. Most of Detroit's current housing stock was built for workingmen and their families: modest homes with few features, no architectural merit, and sited on tiny plots. Will the population stabilize or fall in those neighborhoods where thousands of homes were built in the early years of the auto boom and just after World War II? The quality of life in such neighborhoods will be crucial (Helms and Guillen 2014). There are signs of improvement. In 2013, just over one-half of the city's street lights worked. Shortly after taking their offices, Kevyn Orr and Mayor Duggan collaborated upon a program to reestablish light on the city's streets. By the fall of 2014, many neighborhoods once again had lights. Lacking resources to purchase new equipment, local entrepreneurs Dan Gilbert and Roger Penske raised funds to purchase 100 new patrol cars and 23 EMS vehicles which were loaned to the city. Perhaps no large city in the country has a public transportation system as minimalist as Detroit. Private and foundation monies are paying three-quarters of the cost of a modern light rail system to link Downtown and Midtown. Detroit had seven different police chiefs in the 4 years before bankruptcy. Kevyn Orr recruited a former Detroit police officer who had been laid off in 1980, but then went on to become chief of police in Cincinnati. That chief implemented new strategies and reported, in the fall of 2014, that violent crimes had fallen 8 percent and property crime by 21 percent since 2013 (City of Detroit 2014). Murders in Detroit peaked at 714 in 1974, but decreased to 304 in 2014 (Hunter 2015).

There are many active groups and individuals with innovative ideas about how to revitalize or reuse neighborhoods (Gallagher 2010, 2013). Detroit financier John Hantz secured title to several hundred parcels on the East Side and planted what will become the nation's largest urban forest. In two neighborhoods, Habitat for Humanity is constructing several hundred moderately priced homes. A number of artists, urban farm advocates, and imaginative young people are seeking to improve the quality of life in the remote Morningside neighborhood. The Write-a-House endeavor is purchasing foreclosed homes, rehabbing them, and then making them available to poets and writers who win a competition to spend a creative year in Detroit. The task of rebuilding and repopulating Detroit is a huge one, but the steps taken during bankruptcy are more positive, innovative, and promising.

Will these revitalize Detroit or will the city return to a fiscal crisis a few years in the future? The pessimistic view is lucidly described by Brian Doucet (2015). He contends that current revitalization efforts are concentrated in just 5 percent of the city's land area. They may attract highly skilled workers and some residents, but these efforts will not address the poverty, unemployment, and lack of access to good education for the vast majority of the city's residents. Gentrification, he observes, will contribute to greater inequality and polarization. And the racial distinction between the gentrified 5 percent of Detroit and the low-income 95 percent will be great. 
But there is also an optimistic view. Bringing more jobs in technology, finance, and health care creates employment opportunities for both those with high skills and those who are likely to work in service and entertainment industries. A dynamic and growing core will lead to greater tax revenue for the city and, presumably, to the revitalization of adjoining neighborhoods. For the first time, the city has resources to stabilize some neighborhoods and remove blight structures from others. Foundations are supporting efforts to improve education and health services throughout the city and the state of Michigan is once again making an effort to reform the city's schools. These are challenging tasks but for the first time major efforts are being made to address many of the city's problems. There is also an emergence of city-suburban cooperation. After 25 attempts, the state legislature in 2013 established a body to coordinate and manage a metropolitan transportation system in Detroit. Suburban residents, that year, voted to raise their property taxes to support the Detroit Institute of Art. The water and sewerage system for southeast Michigan had been owned and managed by the city. As a result of Detroit's bankruptcy, the state mandated that the city and suburbs mutually run the system. These are small steps but are substantial ones in the context of the bitter city-suburban and black-white conflicts that divided the metropolis for decades.

\section{THE CIVIL RIGHTS REVOLUTION AND ITS IMPLICATIONS FOR THE FUTURE OF DETROIT}

For decades, Detroit activists played key roles in the struggle for equal opportunities. Those efforts were successful in the 1960s, with the passage of the Civil Rights Act, the Voting Rights Act, and the Open Housing Law. Racial attitudes of whites shifted as younger cohorts with more liberal views became adults. Federal courts frequently overturned state, local, and employer policies that unfairly protected the advantages of whites. In metropolitan Detroit, racial changes occurred in three areas: occupations, interracial marriage, and residential segregation.

In 1970, only 8 percent of professional/managerial jobs in the area were held by blacks; in 2013, that increased to 13 percent. Although the UAW supported civil rights, traditional Jim Crow practices kept most blacks out of the skilled trades jobs until the 1960s. Changes occurred as employment barriers fell. As a result, highly educated and skilled blacks improved their economic standing. The per capita income of adults in the top 10 percent of the black income distribution rose from $\$ 75,300$ in 1970 to $\$ 92,900$ in 2013 (constant 2013 dollars) and the percent of black households with income five times the poverty line grew from 10 to 12 percent.

Social integration is occurring as Detroit-area blacks and whites increasingly intermarry. In 1970, only 2 percent of younger black married men had white wives. In 2013, it was 7 percent. Because of interracial marriage, mixed race population is growing and 1 in 33 Detroit area children under 10 are now listed by their parents as both black and white.

The attitudes of whites about the key issue that separated the races in metropolitan Detroit changed as the Open Housing Law helped overturn real estate practices that made Detroit the most segregated metropolis (Farley 2011). No longer are the suburbs closed to blacks. Between 2000 and 2013, the city's black population dropped by 228,000 while the suburban ring gained 167,000 African Americans. The city is now losing black 
WHITES, 1980

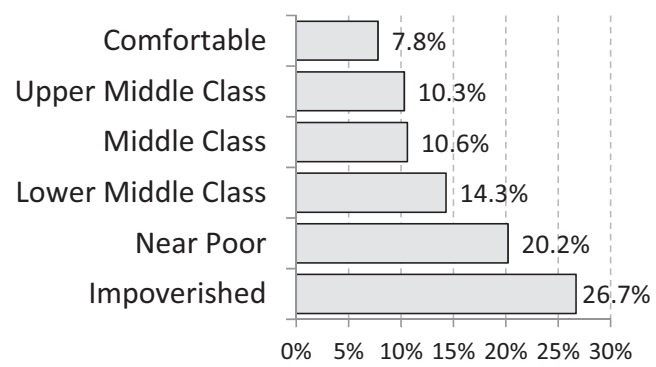

BLACKS, 1980

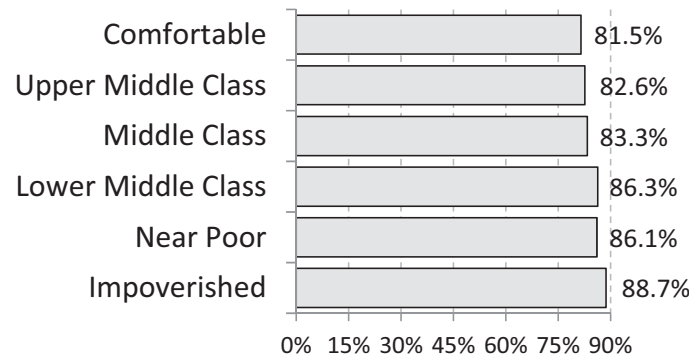

WHITES, 2013

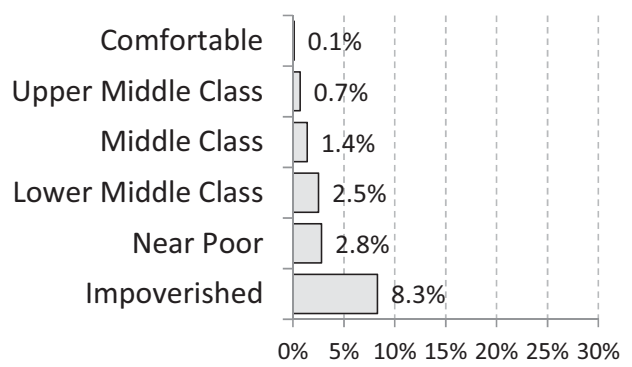

BLACKS, 2013

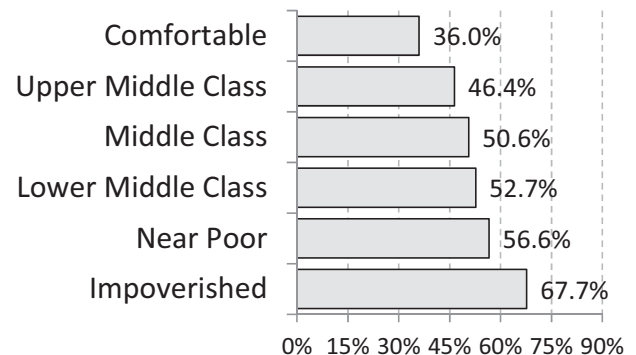

FIG. 2. Percentage of Detroit metropolitan area whites and blacks, classified by economic status, living in the City of Detroit rather in the suburban ring: 1980 and 2013.

Note: Impoverished: incomes below the poverty line. Near poor: incomes 100-199 percent of poverty line.

Lower middle class: incomes 200-299 percent of poverty line; middle class: incomes 300-399 percent of poverty line; upper middle class: incomes 400-499 percent of poverty line; comfortable: at least five times the poverty line.

Source: U.S. Bureau of the Census; Public Use Microdata files from Census 1980 and the 2013 American Community Survey.

residents almost as rapidly just as it lost whites in the past. This black flight has not created homogeneous ghettos in the suburbs. Rather, blacks are now widely distributed throughout the suburbs with substantial numbers residing in suburbs with histories of hostility to blacks (Darden and Thomas 2013, table 52). Farmington Hills, Oak Park, Southfield, and Warren are among the Detroit suburbs that had tiny numbers of black residents in 1970 , but substantial numbers in 2010. In 1980 and 1990, the segregation score for metropolitan Detroit was 88. Census 2010 found low levels of segregation in those Detroit suburbs that had growing black populations: scores of 20 for Farmington Hills, 27 for Southfield, 32 in Warren, and 41 for Oak Park (Logan 2014). Detroit is still a highly segregated metropolis, but residential integration is occurring peacefully in the once all-white suburbs.

The exodus of whites from the city occurred on a selective basis: The most prosperous moved out first, followed later by those with middle and lower incomes. The same selectivity characterizes black suburbanization. Figure 2 categorizes white and black households in metropolitan Detroit into six economic groups ranging from impoverished to those households with five or more times the poverty line or an income in excess of $\$ 137,000$ 
for a family of four in 2013 dollars. Data show the percent of Detroit area households in each economic category living in the city of Detroit rather than in the suburbs.

By 1980, virtually all financially successful white households resided in the suburbs. But among whites below the poverty line, more than one in four were still city residents. A generation later-in 2013-almost all white households lived in the ring regardless of their finances. In 1980, the American Apartheid system closed the suburbs to African Americans so blacks lived in the city regardless of their resources. But that changed and, by 2013, the majority of black households with a middle class income or better now live in the suburbs. This out-migration seems likely to continue as Detroit blacks seek to live in places that are perceived to be safer, have better schools, and offer better services than Detroit. Substantial changes in the quality of Detroit neighborhoods and schools will be needed to attract and retain prosperous residents.

The election of Michael Duggan as mayor of Detroit in November 2013 is another prominent indicator of how racial attitudes have changed. Duggan grew up in the city of Detroit and, following the demographic trends of his era, moved to the suburbs where he prospered as a health system administrator and county official. He returned to Detroit in 2012 and then handily defeated Benny Napoleon, the African American county sheriff. An electorate that was 82 percent African American chose the first white mayor in 40 years, an outcome that was unimaginable during the Coleman Young years when racial conflict and city-suburban hostility infused every issue.

\section{THE TREATY OF DETROIT AND ITS IMPLICATIONS}

The labor agreement that the Big Three auto producers reached with the UAW after World War II created a secure blue-collar middle class. Census 1950 reported that adult men in Detroit had per capita earnings 8 percent greater than those of men in Chicago, New York, San Francisco, or Washington. For black men, the financial advantage to working in Detroit was even larger. That is no longer the situation for a variety of reasons linked to how and where vehicles are built. A major change occurred when the Organization of Petroleum Exporting Countries embargoed oil shipments from the Middle East in 1973, triggering a surge in gas prices. For the first time, it became imperative for U.S. firms to produce high-quality, fuel-efficient cars to compete with imports. They found this challenging so their share of the market declined sharply. Auto firms needed to reduce costs and improve quality. They shifted production away from high cost areas, leading to a stagnation, then sharp decline of employment in Michigan. To be sure, the Treaty of Detroit was not the only and probably not the major reason for a stagnation of industrial employment in Michigan, but it was a factor. Automation is one effective solution to high labor costs and quality issues. An active trade group promoted southeast Michigan as "Automation Alley"-a place where engineers and scientists would develop labor saving machines. That endeavor was a success. Since the late 1980s, labor productivity in the vehicle industry has increased steadily by 6 percent per annum (U. S. Bureau of Labor Statistics 2014b). Most firms would be pleased with a year-to-year 6 percent increase in sales. In the vehicle industry, such growth can be accomplished without the addition of assembly line workers.

When firms automated production and shifted to lower wage areas, they did so for other than racial reasons. But the huge change in employment was far from neutral with regard to race. The black middle class was much more dependent on manufacturing jobs 
TABLE 1. Economic Indicators for Blacks and Whites in the Detroit Metropolitan Area: 1970 and 2013

\begin{tabular}{|c|c|c|c|}
\hline Year & White & Black & Racial Gap (Black-White) \\
\hline \multicolumn{4}{|c|}{ Median household income in 2013 dollars } \\
\hline 1970 & $\$ 70,300$ & $\$ 48,200$ & $-\$ 22,100$ \\
\hline 2013 & 59,700 & 30,200 & $-\$ 29,500$ \\
\hline \multicolumn{4}{|c|}{ Per capita income of adult ( 25 to 64 ) men in 2013 dollars } \\
\hline 1970 & $\$ 67,600$ & $\$ 40,700$ & $-\$ 26,900$ \\
\hline 2013 & 59,900 & 28,200 & $-\$ 31,700$ \\
\hline \multicolumn{4}{|c|}{ Per capita income of adult women in 2013 dollars } \\
\hline 1970 & $\$ 16,000$ & $\$ 16,200$ & $+\$ 200$ \\
\hline 2013 & 33,800 & 26,700 & $-7,100$ \\
\hline \multicolumn{4}{|c|}{ Percentage of adult men employed } \\
\hline 1970 & $91 \%$ & $81 \%$ & $-10 \%$ \\
\hline 2013 & 78 & 55 & -23 \\
\hline \multicolumn{4}{|c|}{ Percentage of adult women employed } \\
\hline 1970 & $40 \%$ & $48 \%$ & $+8 \%$ \\
\hline 2013 & 68 & 60 & -8 \\
\hline \multicolumn{4}{|c|}{ Percentage of total population impoverished } \\
\hline 1970 & $5 \%$ & $18 \%$ & $-6 \%$ \\
\hline 2013 & 12 & 33 & -21 \\
\hline \multicolumn{4}{|c|}{ Percentage of children under 18 impoverished } \\
\hline 1970 & $4 \%$ & $26 \%$ & $-22 \%$ \\
\hline 2013 & 17 & 47 & -30 \\
\hline \multicolumn{4}{|c|}{ Percentage of households owning their home or condo } \\
\hline 1970 & $75 \%$ & $53 \%$ & $-22 \%$ \\
\hline 2013 & 77 & 44 & -33 \\
\hline \multicolumn{4}{|c|}{ Median value of owner-occupied homes and condos } \\
\hline 1970 & $\$ 143,200$ & $\$ 103,300$ & $-\$ 39,900$ \\
\hline 2013 & 130,000 & 50,000 & $-80,000$ \\
\hline
\end{tabular}

Source. U.S. Bureau of the Census, Public Use Microdata Samples from Census 1970 and the 2013 American Community Survey.

than the white middle class. In 1970, just under one-third of all blacks employed in the Detroit area worked for manufacturers-about double the proportion of whites. Thus, the disappearance of jobs and the decline in wages in manufacturing had devastating consequences for blacks. To be sure, those at the top end of the income distribution have weathered the storm of employment restructuring, but the typical resident of metropolitan Detroit-white or black-is much less economically secure now than a generation ago.

Table 1 uses 10 common economic indicators to describe the economic status of Detroit-area blacks vis-à-vis whites at the start of industrial restructuring and in the present. All amounts are in 2013 dollars. The median income of white households fell by $\$ 11,000$ in a generation, but among blacks, it was a much greater drop of $\$ 18,000$ leading to a larger racial gap as shown in the right-hand column of this table. On a per capita basis, black men in 1970 had incomes $\$ 26,000$ less than those of white men. White men saw their incomes fall sharply, but the decline was greater among blacks so that racial gap grew to $\$ 32,000$. Blacks lagged far behind whites in purchasing power in 1970 , but they were even further behind in 2013. 
In 1970, black women were more likely to be employed and had, on average, higher incomes than white women, but by 2013, that was reversed. In 1970, three-quarters of adult black men were employed, but in 2013, just over one-half of black men went to work. Poverty increased substantially among whites, but more among blacks. Racial gaps in home ownership and value of owned homes became substantially larger, suggesting that blacks fell further behind whites in asset holdings too.

What explains the deterioration in the economic status of African Americans? It cannot be attributed to an increase in the traditional racial discrimination that, prior to the Civil Rights Revolution, kept blacks out of white neighborhoods and excluded them from the most rewarding jobs. The disappearance of the highly-paid, blue-collar jobs is the most important cause. In 1970, 102,000 black men in the Detroit area worked in manufacturing, transportation, utilities, and construction-the industries where wages were highest. The multibillion dollar investments that Ford, General Motors, and Fiat/Chrysler are now making in Detroit area plants mean that more cars will be produced there, but there may be few new jobs. By 2013, only 53,000 black men worked in manufacturing, transportation, utilities, and construction. The average earnings of those men-in constant 2013 dollars-were $\$ 44,700$ in 1970 , but fell to $\$ 38,100$ in 2013 . The key jobs that once sustained a large and financially secure black middle class in Detroit disappeared.

\section{CONCLUSION}

The Kerner Commission provided the most convincing and perceptive explanation for the urban racial violence of the 1960s. And it accurately forecast the demographic future of metropolitan Detroit, for at least a generation. But it missed two major changes that turned out to play major roles in the bankruptcy of Detroit. First, racial attitudes changed. Neighborhoods and occupations that were once overwhelmingly white gradually became open to African Americans who had the requisite education, skills, and resources to take advantage of this development. Neither the Kerner Commission nor any other analyst forecast the great changes in the labor market. The demand for moderately skilled labor has greatly declined, and wages for all but those at the top of the earnings distribution have fallen. In the Detroit area, the African American population was particularly affected since the black middle class was largely supported the manufacturing jobs that automation eliminated. Thus, race played a role in Detroit's bankruptcy and will play a role in the city's future, but in a more complex manner than the Kerner Commission had suggested.

\section{Note}

\footnotetext{
${ }^{1}$ Unless otherwise noted, demographic data are from the Public Use Microdata Files from the American Community Survey, the decennial censuses, and the Current Population Survey available from the University of Minnesota Population Center (Ruggles, Steven et al. 2010). Additional tabulations of these data were obtained from Social Explorer (www.socialexplorer.com).
}

\section{REFERENCES}

Aguilar, Louis. 2014. "Packard Plant Owner Charms East Side," Detroit News. November 7.

Baime, A. J. 2014. The Arsenal of Democracy: FDR, Detroit, And an Epic Question to Arm an America at War. Boston: Houghton, Mifflin. 


\section{CITY \& COMMUNITY}

Baugh, Joyce A. 2011. The Detroit School Busing Case: Milliken v. Bradley and the Controversy over Desegregation. Lawrence, KS: University of Kansas Press.

Boyle, Kevin. 2004. Arc of Justice: A Saga of Race, Civil Rights, and Murder in the Jazz Age. New York: Henry Holt \& Co.

Brooks, Richard R. W., and Carol M. Rose. Saving the Neighborhood: Racially Restrictive Covenants, Law, and Social Norms. Cambridge, MA: Harvard University Press.

Brown v. Board of Education of Topeka, 1954. 347 U. S. 483.

Capeci, Dominic J. Jr. 1984. Race Relations in Wartime Detroit. Philadelphia: Temple University Press.

Capeci, Dominic J. Jr., and Martha Wilkerson. 1991. Layered Violence: The Detroit Rioters of 1943. Jackson, MS: University of Mississippi Press.

Citizens Research Council of Michigan. 2013. Detroit City Government Revenues. Report \#382 (April). Lansing: Citizens Research Council of Michigan.

City of Detroit. 2014. Police Department, Crime Statistics. http://www.detroitmi.gov/Departmentsand Agencies/PoliceDepartment/CrimeStatistics.aspx

Darden, Joe T., and Richard W. Thomas. 2013. Detroit: Race Riots, Racial Conflicts, and Efforts to Bridge the Racial Divide. East Lansing: Michigan State University Press.

Desjarlais, Mary. 2008. Beauty on the Streets of Detroit: A History of the Housing Market in Detroit. Ferndale, MI: Cambourne Publishing.

Dolan, Matthew. 2014. "Mayor Aims to Reverse Detroit Exodus.” Wall Street Journal, June 22.

Doucet, Brian. 2015. "Gentrification in Detroit." The Guardian, February 17.

Farley, Reynolds. 2011. "Black-White Residential Segregation: The Waning of American Apartheid," Contexts $10(3): 36-43$.

Fine, Sidney. 1969. Sit Down: the GM Strike of 1936-1937. Ann Arbor: University of Michigan Press.

Freund, David M. P. 2007. Colored Property: State Policy $\mathcal{E}^{2}$ White Racial Politics in Suburban America. Chicago: University of Chicago Press.

Gallagher, John. 2010. Reimaging Detroit: Opportunities for Redefining an American City. Detroit: Wayne State University Press.

. 2013. Revolution Detroit: Strategies for Urban Reinvention. Detroit: Wayne State University Press.

— , 2014. "One Downtown, Two Empires." Detroit Free Press. July 27.

Good, David L. 1989. Orvie: The Dictator of Dearborn: The Rise and Reign of Orville L. Hubbard. Detroit: Wayne State University Press.

Helms, Matt, and Joe Guillen. 2014. “The Change in Detroit is Real': Mayor Mike Duggan Promises Better Parks, Cheaper Insurance in State of City.” Detroit Free Press, February 26.

Hunter, George. 2015. “Detroit Homicides Fall in 2014.” Detroit News. January 2.

Jackson, Kenneth T. 1967. The Ku Klux Klan in the City: 1915-1930. New York: Oxford University Press.

Lichtenstein, Nelson. 1995. The Most Dangerous Man in Detroit: Walter Reuther and the fate of American Labor. New York: Basic Books.

Logan, John. 2014. US2010. Discover America in a New Century. http://www.s4.brown.edu/us2010/index.htm

Martinez, Michael. 2015. "Detroit Industrial Park May Get Auto Supplier." Detroit News. March 1.

Massey, Douglas, and Nancy Denton. 1993. American Apartheid: Segregation and the Making of the Underclass. Cambridge, MA: Harvard University Press.

Meier, August, and Elliott Rudwick. 1979. Black Detroit and the Rise of the UAW. New York: Oxford University Press.

National Advisory Commission on Civil Disorders. 1968. Report of the National Advisory Commission on Civil Disorders (aka The Kerner Commission Report). Washington, DC: Government Printing Office.

Oosting, Jonathan. 2014. "How Michigan's Revenue Sharing 'Raid' Cost Communities Billions for Local Services." MLIVE (www.mlive.com), March 30.

Ruggles, Steven J., Trent Alexander, Katie Genadek, Ronald Goeken, Matthew B. Schroeder, and Matthew Sobek. 2010. Integrated Public Use Microdata Series: Version 5.0 [Machine-readable database]. Minneapolis: University of Minnesota.

Schaefer, Jim. 2013. "Kwame Kilpatrick Public Corruption Trial Evidence Revealed." Detroit Free Press, March 12.

Shogan, Robert, and Tom Craig. 1964. The Detroit Race Riot: A Study in Violence. Philadelphia: Chilton Books. Snell, Robert. 2014. "Kilpatrick frat brother Beasley convicted of conspiracy." Detroit News, December 9.

Spreen, Johannes F., and Diane Holloway. 2005. Who Killed Detroit? Other Cities Beware! New York: iUniverse.

Sugrue, Thomas. 1998. The Origins of the Urban Crisis: Race and Inequality in postwar Detroit. Princeton, NJ: Princeton University Press. 
U. S. Bureau of Labor Statistics. 2014a. Local Area Employment Data, http://www.bls.gov/lau/

- 2014b. Indexes of Labor Productivity, http://data.bls.gov/cgi-bin/dsrv

Vine, Phyllis. 2004. One Man's Castle: Clarence Darrow in Defense of the American Dream. New York: Harper, Collins.

Vose, Clement. 1959. Caucasians Only: The Supreme Court, the NAACP and the Restrictive Covenant Cases. Berkeley: University of California Press.

White, Ed. 2010. "Monica Conyers, Wife to John Conyers, Sentenced to 3 Years In Prison for Detroit Bribes." The Huffington Post (May 25).

Williams, Paige. 2014. "Drop Dead Detroit! The Suburban Kingpin Who is Thriving off the City's Decline." New Yorker (January 27).

Wolf, Eleanor. 1981. Trial and Error: The Detroit School Desegregation Case. Detroit: Wayne State University Press.

Yaccino, Steven. 2013. "Kwame M. Kilpatrick, Former Detroit Mayor, Sentenced to 28 Years in Corruption Case." The New York Times, October 10.

Young, Coleman, and Lonnie Wheeler. 1994. Hard Stuff: The Autobiography of Mayor Coleman Young. New York: Viking.

\section{La Bancarrota de Detroit: ¿Qué Papel Jugó la Raza?}

\section{Resumen}

Quizás ninguna ciudad en los Estados Unidos tiene una historia más larga y más viva de conflicto racial que Detroit. Es la única ciudad en donde tropas federales fueron enviadas a las calles cuatro veces para terminar con matanzas raciales. Para los años 90, Detroit era por excelencia la metrópolis "Ciudad de Chocolate - Suburbios de Vainilla". Detroit, en el 2013, fue la ciudad más grande en entrar en bancarrota. Es una sobre-simplificación y es desacertado decir que el conflicto racial y la segregación causan la bancarrota de Detroit. Pero los temas raciales han estado profundamente entrelazados con cambios poblacionales importantes y con cambios en el empleo que disminuyeron la base tributaria de la ciudad. También se toma en consideración el rol que la continuidad de la disparidad racial jugará en el futuro de Detroit luego de la bancarrota. 